\title{
Adult Plant Leaf Rust Resistance in AC Taber Wheat Maps to Chromosomes 2BS and 3BS
}

\author{
J. A. Kolmer, ${ }^{1, \dagger}$ M. K. Turner, ${ }^{2}$ M. N. Rouse, ${ }^{1}$ and J. A. Anderson ${ }^{2}$ \\ ${ }^{1}$ Cereal Disease Laboratory, U.S. Department of Agriculture Agricultural Research Service, St. Paul, MN 55108 \\ 2 Department of Agronomy and Plant Genetics, University of Minnesota, St. Paul, MN 55108 \\ Accepted for publication 27 July 2020.
}

\begin{abstract}
AC Taber is a hard red spring wheat cultivar that has had long-lasting resistance to the leaf rust fungus Puccinia triticina. The objective of this study was to determine the chromosome location of the leaf rust resistance genes in AC Taber. The leaf rust-susceptible cultivar Thatcher was crossed with $\mathrm{AC}$ Taber to develop an $\mathrm{F}_{6}$ recombinant inbred line (RIL) population. The RILs and parents were evaluated for segregation of leaf rust resistance in five field plot tests and in two seedling tests to race BBBDB of $P$. triticina. A genetic map of the RIL population was developed using 90,000 single nucleotide polymorphism markers with the Illumina Infinium iSelect $90 \mathrm{~K}$ wheat bead array. Quantitative trait loci
\end{abstract}

ABSTRACT

Leaf rust, caused by the fungus Puccinia triticina Erikss., is an important disease of wheat (Triticum aestivum L.) in continental and coastal regions where wheat matures in warm to hot temperatures in nonarid conditions (Saari and Prescott 1985). Leaf rust is very widely distributed throughout the United States and Canada on an annual basis, often being observed on winter wheat in the Gulf Coast region in February (Kolmer 2019) and by mid to late August in central Saskatchewan (McCallum et al. 2018). In the north central Great Plains of the United States and Canada where hard red spring wheat is primarily grown, leaf rust is the most common and regularly occurring disease of wheat. Since the 1960s, many of the hard-red spring wheat cultivars in this region have had the adult plant resistance genes Lrl3 and Lr34 (Kolmer et al. 2008; Oelke and Kolmer 2004, 2005). Although Lrl3 is best expressed in adult plants, this gene is highly race specific and has provided varying levels of resistance over time because of the prevalence of virulent $P$. triticina races (Kolmer et al. 2003). The resistance phenotype conditioned by Lrl3 usually includes mixtures of necrosis and uredinia of varying sizes, often at relatively high severity. In contrast, Lr34 has provided some degree of resistance to all current $P$. triticina races, and wheat lines with $\operatorname{Lr34}$ often have mixtures of uredinia of different sizes, without necrosis or distinct chlorosis, at moderate to high severity. Cultivars that have both Lr13 and Lr34 have had long-lasting effective resistance to leaf rust, even with the continual selection of virulent races owing to other race-specific resistance genes in

†Corresponding author: J. A. Kolmer; jim.kolmer@usda.gov

Funding: This research was supported by the USDA Agriculture and Food Research Initiative (2011-68002-30029 Triticeae Coordinated Agricultural Project) to M. K. Turner.

*The $\boldsymbol{e}$-Xtra logo stands for "electronic extra" and indicates that two supplementary tables are published online.

The author(s) declare no conflict of interest.

This article is in the public domain and not copyrightable. It may be freely reprinted with customary crediting of the source. The American Phytopathological Society, 2021.
(QTLs) with significant effects for lower leaf rust severity in the field plot tests were found on chromosomes 2BS and 3BS. The same QTLs also had significant effects for lower infection type in seedlings to leaf rust race BBBDB. The gene on 2BS was the adult plant resistance gene Lr13, and the gene on $3 \mathrm{BS}$ mapped to the same region as the adult plant resistance gene $\operatorname{Lr} 74$ and other QTLs for leaf rust resistance. Kompetitive allelespecific PCR assay markers linked to the $2 \mathrm{BS}$ and $3 \mathrm{BS}$ regions were developed and should be useful for marker-based selection of these genes.

Keywords: disease resistance, genetics, resistance winter and spring wheat cultivars (Kolmer and Hughes 2018). For example, cultivar Chris, the first hard red spring wheat in the United States with $L r 13$ and $L r 34$ and released in 1966, continues to have moderate leaf rust resistance in inoculated field plots (J. A. Kolmer, unpublished data).

The Canadian spring wheat AC Taber with the pedigree of HY320*2/BW553 was licensed for release in 1991 in the Canada Prairie Spring class (Knox et al. 1992). A genetic study indicated that AC Taber had Lrl3 plus an unidentified adult plant leaf rust resistance gene (Liu and Kolmer 1997) that was temporarily designated as $L r T b$. Derived lines homozygous for this gene had field leaf rust responses of flecks and small uredinia with chlorosis at low severity levels that were phenotypically different from $\operatorname{Lr} 34$. Although no longer widely grown in Canada, AC Taber has continued to have highly effective leaf rust resistance and may be a source of additional leaf rust resistance that can be utilized by wheat improvement projects. The objectives of this study were to determine the genetics of leaf rust resistance in AC Taber by crossing the cultivar with a leaf rust-susceptible parent, developing inbred lines, phenotyping the lines for leaf rust response in field plot and seedling tests, and using current DNA marker technology in wheat to determine the chromosome location of the segregating resistance genes.

\section{MATERIALS AND METHODS}

Population development. Adult plants of AC Taber were used as the pollen parent in a cross with the leaf rust-susceptible wheat cultivar Thatcher, and $183 \mathrm{~F}_{2}$-derived $\mathrm{F}_{6}$ recombinant inbred lines (RILs) were advanced by single seed descent in a greenhouse and tested in the $\mathrm{F}_{7}$ generation.

Leaf rust phenotyping. The RILs and parental cultivars were evaluated for field reaction at St. Paul, Minnesota, from 2013 to 2016, and at Crookston, Minnesota, in 2013. In St. Paul, 50 to 60 seeds of each RIL and parents were planted in 2-m rows spaced 30 $\mathrm{cm}$ apart, at right angles to spreader rows of the wheat cultivars Thatcher, Morocco, Max, and Little Club that are all susceptible to leaf rust. In Crookston in 2013, the RILs and parents were planted in the same arrangement, but with spreader rows of Max planted after 
every 25 rows of RILs. Mixtures of $P$. triticina races common in the United States (Kolmer and Hughes 2015, 2017) were used to inoculate the plots at St. Paul and Crookston. Isolates with the race designations of MHDSB, MFPSB, MLDSD, TBBGJ, TFBJQ, and TFBGQ were used to inoculate the spreader rows at St. Paul and Crookston in 2013; races MHDSB, MFPSB, TBBGJ, TFBJQ, TFBGQ, and TBBGS were used in the plots at St. Paul in 2014; and races MHDSB, MFPSB, MLDSD, TFBGQ, TBBGS, and MJBJG were used at St. Paul in 2015 and 2016. The five-letter code designations of the races were adapted from the original three-letter code in Long and Kolmer (1989) by adding two additional sets of four differentials (Kolmer and Hughes 2017). The spreader rows were inoculated with a suspension of freshly increased urediniospores in Soltrol 170 oil (Chevron-Phillips Petroleum, Bartlesville, OK) at approximately 30 days after planting, when the plants were at the jointing stage.

The RILs and parents were evaluated once for leaf rust severity and response approximately 60 days after planting. The modified Cobb scale (Peterson et al. 1948) was used to assess the leaf rust severity of flag leaves of the RILs and parents. Five leaves collected from different parts of a row were assessed for severity and response. The RILs and parents were also assessed for leaf rust resistance response as follows: $\mathrm{R}$ indicates necrosis surrounding small uredinia, MR indicates necrosis surrounding moderate-size uredinia, MS indicates distinct chlorosis surrounding moderate to large uredinia, and $\mathrm{S}$ indicates large uredinia lacking necrosis or chlorosis. The severity and response ratings were recorded when the susceptible parent Tc had leaf rust severity of 50 to $80 \%$ with a susceptible response. RILs that headed 4 to 7 days later than Tc were scored 7 days later to allow further leaf rust development on the flag leaves. The field plots at Crookston in 2013 and St. Paul in 2016 were affected by drought conditions that significantly stressed the plants and limited the spread of leaf rust in the plots. Tests in the other years at St. Paul were not affected by dry conditions.

The RILs and parents were also tested as seedlings to race $\mathrm{BBBDB}$. This race is avirulent to most leaf rust resistance genes effective at the seedling stage, with virulence only to lines with Lr14a, Lr14b, and Lr2O among the Thatcher differential lines used to identify races at the U.S. Department of Agriculture-Agricultural Research Service (USDA-ARS) Cereal Disease Laboratory. The RILs and parents were grown in segmented trays with four to six seeds for each RIL in a greenhouse maintained at 20 to $23^{\circ} \mathrm{C}$ and fertilized with 20-20-20 NPK solution at 7 and 14 days after planting. When the primary leaves were fully expanded at 7 to 8 days after planting, the seedlings were inoculated with a single race of $P$. triticina using a suspension of urediniospores in Soltrol 170 oil. After inoculation, the plants were dried for $1 \mathrm{~h}$ and then placed in a dew chamber overnight at $18^{\circ} \mathrm{C}$. The plants were then returned to a greenhouse bench at 20 to $23^{\circ} \mathrm{C}$ with supplemental lighting. Infection types (ITs) were scored on a 0 to 4 scale 10 days after inoculation. ITs 0 (immune response); (hypersensitive fleck), 1 (small necrotic uredinia), and 2 (small-size uredinia with prominent chlorosis) were considered avirulent. ITs 3 (moderate-size uredinia lacking necrosis or chlorosis) to 4 (large uredinia) were considered virulent. Lines with mixed ITs were described with the most common IT first. Minus and plus signs denoted smaller or larger uredinia, respectively. For QTL mapping, RILs with resistant ITs were coded as 1 and RILs with susceptible ITs were coded as 0 for a binary analysis. To account for the range of resistant ITs, the ITs were also coded with a 1 to 9 scale, with IT; equal to 0 and IT 4 equal to 9. The RILs and parents were tested as seedlings with race BBBDB at two different times.

Genotyping, mapping, and QTL analysis. Restrictionquality DNA of the parents and RILs was isolated using the cetrimonium bromide method (Akbari et al. 2006). Genotyping was done with the Infinium iSelect $90 \mathrm{~K}$ wheat bead chip array described in Wang et al. (2014) at the USDA ARS Genotyping Center in Fargo, North Dakota. Genome Studio version 2011.1 (Illumina 2011) was used to call single nucleotide polymorphism (SNP) genotypes for the RILs and parents. A total of 11,802 SNP markers segregated in the RILs. SNP markers that showed complete linkage

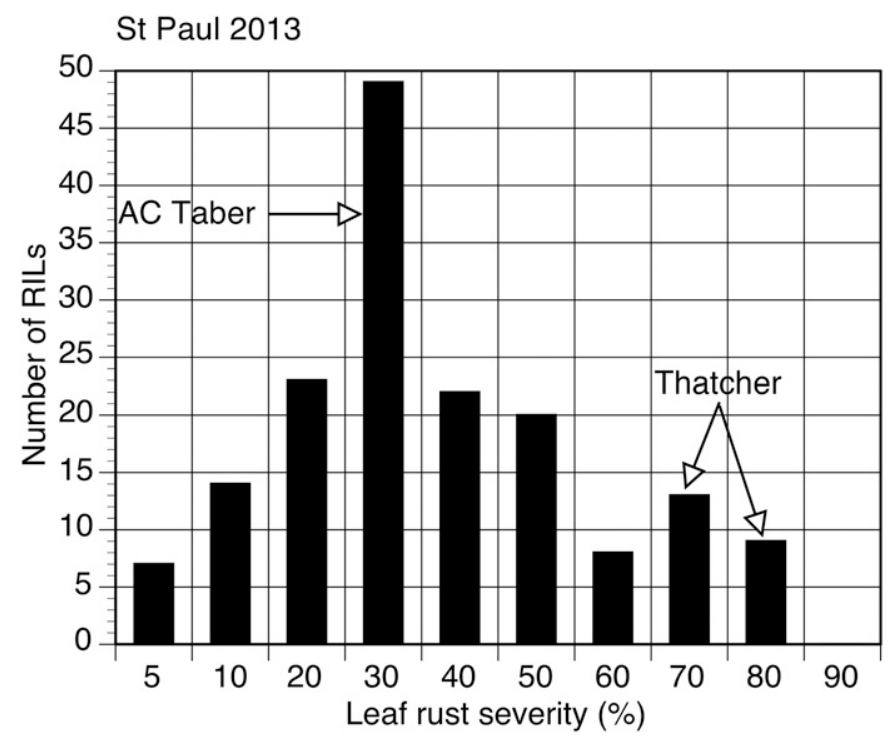

Fig. 1. Distribution of leaf rust severity in Thatcher $\times A C$ Taber $F_{6}$ recombinant inbred lines (RILs) in St. Paul 2013, Minnesota.

TABLE 2. Pearson correlation coefficient of leaf rust severity of Thatcher $x$ AC Taber recombinant inbred lines in five field tests

\begin{tabular}{lccccc}
\hline Trial & $\begin{array}{c}\text { St. Paul } \\
2013\end{array}$ & $\begin{array}{c}\text { Crookston } \\
2013\end{array}$ & $\begin{array}{c}\text { St. Paul } \\
2014\end{array}$ & $\begin{array}{c}\text { St. Paul } \\
2015\end{array}$ & $\begin{array}{c}\text { St. Paul } \\
2016\end{array}$ \\
\hline St. Paul 2013 & $-\mathrm{y}$ & & & & \\
Crookston 2013 & $0.399^{\mathrm{z}}$ & - & & & \\
St. Paul 2014 & $0.689^{\mathrm{z}}$ & $0.399^{\mathrm{z}}$ & - & & \\
St. Paul 2015 & $0.671^{\mathrm{z}}$ & $0.327^{\mathrm{z}}$ & $0.849^{\mathrm{z}}$ & - & \\
St. Paul 2016 & $0.597^{\mathrm{z}}$ & $0.369^{\mathrm{z}}$ & $0.628^{\mathrm{z}}$ & $0.646^{\mathrm{z}}$ & - \\
\hline
\end{tabular}

y Dashes indicate same test.

z Significant correlation at $P<0.001$.

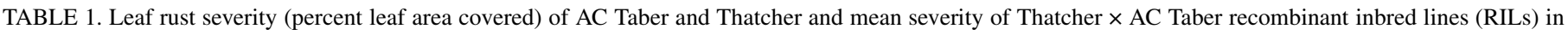
five field tests

\begin{tabular}{|c|c|c|c|c|c|c|c|}
\hline \multirow[b]{2}{*}{ Trial } & \multicolumn{2}{|c|}{ Parents } & \multicolumn{5}{|c|}{ RILs } \\
\hline & AC Taber & Thatcher & RILs tested $(n)$ & Mean & SE & Minimum severity & Maximum severity \\
\hline St. Paul 2013 & $30 \mathrm{MR}$ & $70-80 \mathrm{~S}$ & 165 & 36.9 & 3.27 & 5.0 & 80.0 \\
\hline Crookston 2013 & $5 \mathrm{R}$ & $70-80 \mathrm{~S}$ & 178 & 37.1 & 1.98 & 5.0 & 70.0 \\
\hline St. Paul 2014 & 20-30 RMR & $70-80 \mathrm{~S}$ & 181 & 47.7 & 1.61 & 5.0 & 80.0 \\
\hline St. Paul 2015 & $5 R$ & $70-80 \mathrm{~S}$ & 181 & 44.6 & 1.62 & 5.0 & 80.0 \\
\hline St. Paul 2016 & 5RMR & $70-80 \mathrm{~S}$ & 182 & 42.7 & 1.14 & 5.0 & 80.0 \\
\hline
\end{tabular}


(100\%) and markers missing in more than $5 \%$ of the RILs were removed using the BIN function in QTL ICIMapping (Meng et al. 2015). Markers that had SNP designation that mapped to multiple chromosomes were also removed. Groups of markers were assembled with Mapmaker version 2.0 for MacIntosh (Lander et al. 1987) with the Kosambi mapping function logarithm of odds (LOD) of 10 and recombination fraction of 0.3. Large groups of SNP markers were grouped with more strict criteria of LOD of 4 and recombination fraction of 0.2 to divide the markers into small and more manageable groups. The program R/qtl (Broman et al. 2003) was used to confirm marker order. The program QGENE (Nelson 1997) was used for composite interval mapping (CIM). The SNP marker closest to the LOD peak was selected by QGENE as a cofactor. The coefficient of determination $\left(R^{2}\right)$ and LOD scores for each marker interval were determined with a significance level of $\alpha=$ 0.05 with 1,000 permutations of the dataset. The location of markers associated with lower leaf rust severity (Supplementary Table S1) was confirmed using the 90,000 SNP wheat consensus map (Wang et al. 2014) and the Chinese Spring NRGene-IWGSC genome assembly (http://www.wheatgenome.org/). Analysis of variance of markers and disease severity was conducted with PROC GLM in SAS software (SAS 2012).

After the phenotyping and QTL analysis, SNP markers that were linked with resistance on chromosomes $2 \mathrm{BS}$ and $3 \mathrm{BS}$ were selected for designing kompetitive allele-specific PCR (KASP) markers that were assayed on the parents and the Thatcher wheat line RL4031 that has Lr13. KASP assays followed the standard thermocycler protocol with a reagent mixture of $5 \mu \mathrm{l}$ total described in the LGC Genomics (2013) KASP product manual. PACE Genotyping Master Mix (3CR Biosciences, Harlow, UK) was used. Fluorescence was read using a StepOnePlus Real-Time PCR System and genotypes were determined using StepOne version 2.3 software (Applied Biosystems, Foster City, CA).

\section{RESULTS}

AC Taber varied between $5 \mathrm{R}$ to $30 \mathrm{MR}$ in leaf rust severity and response in the five field plot tests (Table 1) and the susceptible parent Thatcher had severity of 70 to $80 \%$ in all tests. The Tc $\times$ AC Taber RILs segregated widely for leaf rust severity in all five field tests. The RILs varied from 5 to $80 \%$ severity in all tests except for Crookston 2013, where the highest severity was 70\%. The St. Paul 2013 and Crookston 2013 tests had the lowest average severities at less than $40 \%$, whereas the other three tests had average severities greater than
40\%. St. Paul 2013 had the clearest segregation for leaf rust severity among the RILs, and the distribution of severities among the RILs for that trial is shown in Figure 1. RILS with severity of $30 \%$, similar to the rating for $\mathrm{AC}$ Taber, were the most frequent class.

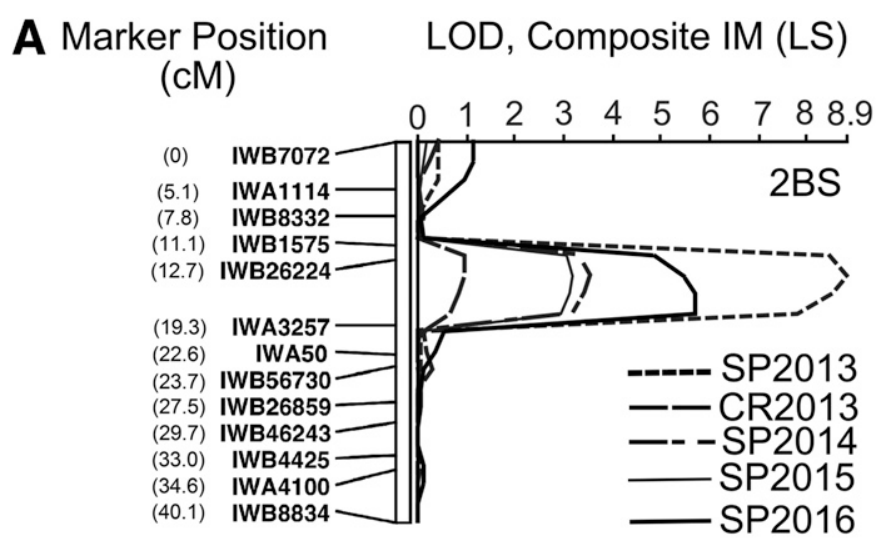

\section{B Marker Position LOD, Composite IM (LS) (cM)}

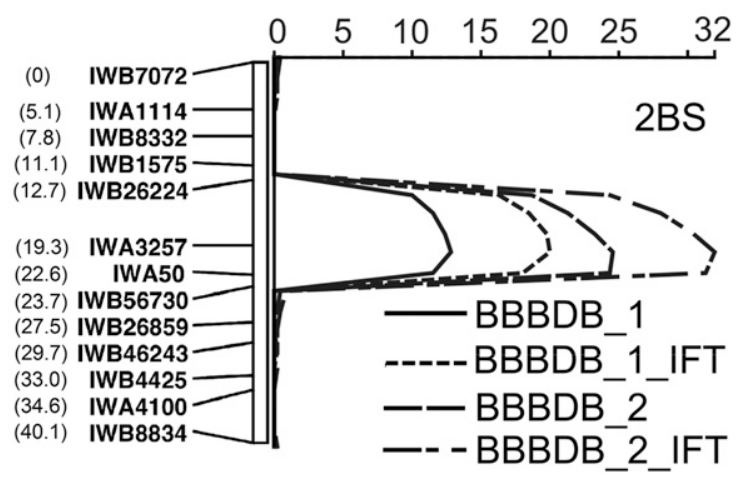

Fig. 2. Composite interval mapping (IM) of leaf rust resistance in the Thatcher $\times$ $\mathrm{AC}$ Taber $\mathrm{F}_{6}$ recombinant inbred line population on chromosome $2 \mathrm{BS}$ in $\mathbf{A}$, field plot tests and $\mathbf{B}$, seedling tests with race BBBDB. $\mathrm{LOD}=$ logarithm of odds, $\mathrm{LS}=$ leaf rust severity, $\mathrm{SP}=\mathrm{St}$. Paul, $\mathrm{CR}=$ Crookston, and IFT = scaled infection type score 1 to 9 .

TABLE 3. Composite interval mapping of leaf rust resistance in the Thatcher $\times$ AC Taber recombinant inbred lines in five field tests and seedling tests with leaf rust race $\mathrm{BBBDB}^{\mathrm{w}}$

\begin{tabular}{|c|c|c|c|c|c|}
\hline QTL & Peak position (cM) & Marker (cM) & Test & $R^{2}$ value & LOD \\
\hline \multirow[t]{7}{*}{ QLr.cdl-2BS } & 14.0 & IWB26224 (12.7) & St. Paul 2013 & 0.22 & 8.82 \\
\hline & & & Crookston 2013 & 0.02 & 0.94 \\
\hline & & & St. Paul 2014 & 0.09 & 3.51 \\
\hline & & & St. Paul 2016 & 0.13 & 5.45 \\
\hline & 20.0 & IWA3257 (19.3) & BBBDB- $1^{\mathrm{x}}$ & 0.28 & 12.92 \\
\hline & & & BBBDB-1 (IT) $)^{\mathrm{y}}$ & 0.40 & 20.04 \\
\hline & & & BBBDB-2 ${ }^{z}$ & 0.47 & 24.51 \\
\hline & & & Crookston 2013 & 0.08 & 3.03 \\
\hline & & & St. Paul 2014 & 0.07 & 2.87 \\
\hline & & & St. Paul 2015 & 0.05 & 1.99 \\
\hline & & & St. Paul 2016 & 0.08 & 3.26 \\
\hline & 24.0 & IWB30730 (20.8) & BBBDB-1 & 0.03 & 1.28 \\
\hline & & & BBBDB-1 (IT) & 0.09 & 3.67 \\
\hline & & & BBBDB-2 & 0.06 & 2.32 \\
\hline
\end{tabular}

${ }^{\mathrm{w}} \mathrm{QTL}=$ quantitative trait locus and LOD $=$ logarithm of odds.

x Seedling test 1 .

${ }^{y}$ Infection type (IT) scale converted to a quantitative 1 to 9 scale.

${ }^{z}$ Seedling test 2 . 
A Marker Position

LOD, Composite IM (LS)

(cM)

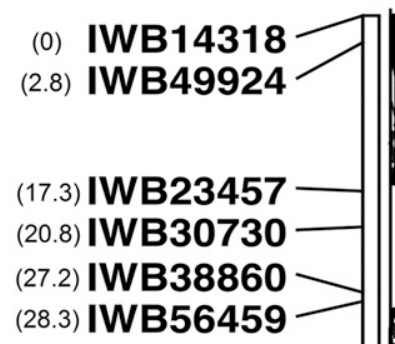

$\begin{array}{lllllllll}0 & 0.5 & 1 & 1.5 & 2 & 2.5 & 3 & 3.5 & 4.1\end{array}$

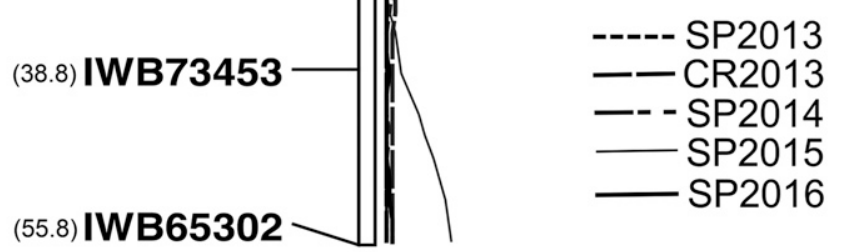

B Marker Position

(cM)

LOD, Composite IM (LS)

$\begin{array}{lllllllll}0 & 0.5 & 1 & 1.5 & 2 & 2.5 & 3 & 3.5 & 4.1\end{array}$

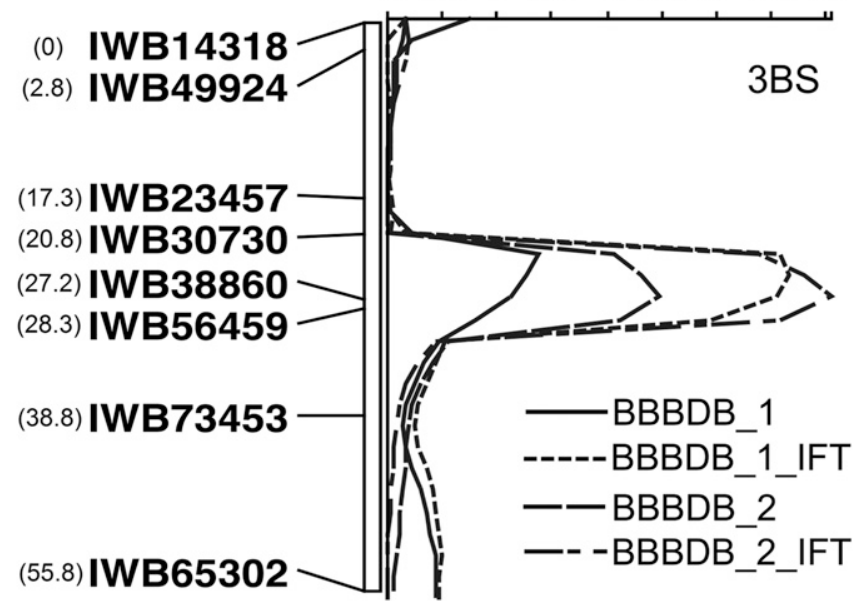

Fig. 3. Composite interval mapping (IM) of leaf rust resistance in the Thatcher $\times$ AC Taber $F_{6}$ recombinant inbred line population on chromosome $3 B$ in $\mathbf{A}$, field plot tests and $\mathbf{B}$, seedling tests with race BBBDB. LOD = logarithm of odds, $\mathrm{LS}=$ leaf rust severity, $\mathrm{SP}=$ St. Paul, $\mathrm{CR}=$ Crookston, and IFT = scaled infection type score 1 to 9.
Except for the Crookston 2013 trial, the leaf rust severities of the RILs in the different trials had correlations of $60 \%$ or greater (Table 2). The correlations with Crookston 2013 were less than 50\%, likely owing to the drought conditions at that location that limited leaf rust spread and increase. The parents and RILs were also tested as seedlings with race BBBDB in two different tests. To this race, AC Taber had an IT of;123, a mixture of hypersensitive flecks, small uredinia with chlorosis, and moderate-size uredinia, and Thatcher had IT $3^{+}$, large uredinia without chlorosis or necrosis. The RILs varied for IT to race BBBDB from; 12 to $3^{+}$.

After removing completely linked SNP markers, markers that mapped to multiple chromosomes, and markers that did not link to other markers, 275 markers on 25 linkage groups that covered $1,809.9 \mathrm{cM}$ were used to construct the genetic map. A linkage group on chromosome $6 \mathrm{~B}$ had the lowest number of markers at 6 , and a linkage group on chromosome $1 \mathrm{~A}$ had the highest number of markers at 22. CIM of leaf rust severity in the five field tests determined two regions associated with lower leaf rust severity (Table 3). A LOD peak at $14.0 \mathrm{cM}$ on chromosome 2BS was identified, with the closest marker IWB26224 located at $12.7 \mathrm{cM}$ (Fig. 2A). This QTL had LOD scores greater than 3.0 in four of the field plot tests and accounted for 9 to $22 \%$ of the total variation in four tests. In the Crookston 2013 test, the LOD score was less than 1.0 with a very low $R^{2}$ value. Another LOD peak at $22.0 \mathrm{cM}$ on chromosome 3BS was identified, with the closest marker IWB30730 at $20.8 \mathrm{cM}$ (Fig. 3A). This QTL had LOD scores greater than 3.0 at St. Paul 2013, Crookston 2013, and St. Paul 2016, with $R^{2}$ values of 8 to $11 \%$.

Lower ITs in the seedling tests with race BBBDB were associated with the same chromosomal regions (Table 3). A LOD peak at 20.0 cM on chromosome 2BS was identified and IWA3257 was the closest marker at $19.3 \mathrm{cM}$ (Fig. 2B). Using both binary scoring and scaled IT scoring, the LOD scores were greater than 10.0, with $R^{2}$ values greater than $25 \%$ for both seedling tests. On chromosome $3 \mathrm{BS}$, the LOD peak for seedling resistance was at $24.0 \mathrm{~cm}$, with IWA30730 the closest marker (Fig. 3B). The LOD score for the scaled IT was greater than 3.0 and was less than 3.0 for the binary data for both seedling tests.

KASP markers for IWA3257, IWB26224, IWB1575, and IWA50 associated with the QTLs on chromosome 2BS were developed (Table 4) and tested on the parental lines and RL4031. AC Taber and RL4031 had the same allele for all four KASP markers, and Thatcher had a different allele. KASP markers were also developed for IWB23457, IWB30730, and IWB38860 associated with the QTLs on chromosome 3BS. AC Taber and Thatcher had different alleles for $K$ IW23457 and the same alleles for K-IWB30370 and K-IWB38860.

A collection of hard red spring wheat cultivars from wheat breeding programs in Minnesota, North Dakota, and South Dakota

TABLE 4. Sequences of kompetitive allele-specific PCR (KASP) markers on chromosomes 2BS and 3BS for leaf rust resistance quantitative trait loci (QTLs) mapped in Thatcher $\times$ AC Taber recombinant inbred lines

\begin{tabular}{|c|c|c|c|c|c|c|c|}
\hline Chromosome & KASP & $\begin{array}{l}\text { AC Taber } \\
\text { allele }\end{array}$ & $\begin{array}{l}\text { Thatcher } \\
\text { allele }\end{array}$ & $\begin{array}{c}\text { RL4031 }\left(\mathrm{Tc} L r 13^{\mathrm{z}}\right) \\
\text { allele }\end{array}$ & $\begin{array}{l}\text { Allele-1 forward } \\
\text { primer }\end{array}$ & $\begin{array}{l}\text { Allele- } 2 \text { forward } \\
\text { primer }\end{array}$ & Common reverse primer \\
\hline \multirow[t]{3}{*}{ 2BS } & $K$-IWA3257 & $\mathrm{T}$ & G & $\mathrm{T}$ & $\begin{array}{c}\text { ATGATCTGATGCA } \\
\text { TGATACGGCAC }\end{array}$ & $\begin{array}{l}\text { CATGATCTGATGC } \\
\text { ATGATACGGCAA }\end{array}$ & $\begin{array}{l}\text { GCGGATGCTTTAT } \\
\text { GATGAAGCACTCAT }\end{array}$ \\
\hline & $K-I W B 1575$ & A & G & A & $\begin{array}{l}\text { GCCTCAAATCAGT } \\
\text { GTCATCTTCATCA }\end{array}$ & $\begin{array}{l}\text { CCTCAAATCAGT } \\
\text { GTCATCTTCATCG }\end{array}$ & $\begin{array}{l}\text { AGGAACTTGCAG } \\
\text { CGTGTTGGTTGAA }\end{array}$ \\
\hline & $K-I W A 50$ & $\mathrm{~T}$ & G & $\mathrm{T}$ & $\begin{array}{l}\text { ATCATCGTCGTA } \\
\text { GCAGGAGTCG }\end{array}$ & $\begin{array}{l}\text { CATCATCGTCG } \\
\text { TAGCAGGAGTCT }\end{array}$ & $\begin{array}{l}\text { CACGCCTCTTGTA } \\
\text { ATCATCAGGACTA }\end{array}$ \\
\hline & K-IWB30730 & A & A & A & $\begin{array}{l}\text { GTCTTCTGCACGC } \\
\text { CTCCGAGT }\end{array}$ & $\begin{array}{l}\text { CTTCTGCAC } \\
\text { GCCTCCGAGC }\end{array}$ & $\begin{array}{l}\text { GGTTGTCGGTGA } \\
\text { AAGCGGCGAT }\end{array}$ \\
\hline & K-IWB38860 & A & A & A & $\begin{array}{l}\text { ACCATCAATTACTT } \\
\text { CTTCATTCGCCAA }\end{array}$ & $\begin{array}{l}\text { CCATCAATTACTT } \\
\text { CTTCATTCGCCAG }\end{array}$ & $\begin{array}{l}\text { CGGTCAATTGG } \\
\text { TGCCCTGCTCTT }\end{array}$ \\
\hline
\end{tabular}

z Thatcher wheat line with $\operatorname{Lr} 13$. 
were tested with the four KASP markers associated with the 2BS QTL and two KASP markers associated with the 3BS QTL (Supplementary Table S2). The cultivars Knudson, Katepwa, Wheaton, Chris, and AC Taber had the same alleles for $K$ $I W A 3257, K-I W B 26224$, and $K-I W B 1575$ as the Thatcher line with Lr13. These cultivars were shown previously to have $L r 13$ in genetic studies (J. Kolmer, unpublished data). Seven other cultivars also had the 2BS QTL based on the allele genotypes for these three KASP markers. Two cultivars, AC Taber and Chris, also had the same allele for $K$-IWA50 as the Thatcher line with $L r 13$ in addition to the alleles for the other three KASP markers associated with Lr13. Six cultivars had the same alleles as AC Taber for markers $K$ $I W B 23457$ and $K-I W B 30730$ that were associated with the QTL on $3 \mathrm{BS}$.

The RILs were placed into four groups based on the presence of resistant and susceptible alleles at $Q L r . c d l-2 B S$ and $Q L r . c d l-3 B S$ (Table 5). In both of the seedling tests with race BBBDB, use of the 1 to 9 IT scale showed that RILs with both QTLs had significantly lower ITs than RILs that had only the 2BS QTL, and RILs that had only the 3BS QTL were not significantly different from RILs that lacked both QTLs. In the field plot tests, RILs with resistance alleles on both chromosomes 2BS and 3BS had significantly lower leaf rust severity in all five tests compared with lines that had susceptible alleles for both QTLs. At St. Paul 2013, RILs with the 2BS and 3BS resistance alleles singly had significantly lower leaf rust severities compared with lines that lacked both resistance alleles. At Crookston 2013 and St. Paul 2014, lines with single resistance alleles did not differ significantly for severity compared with lines that lacked both resistant alleles. In St. Paul 2015 and St. Paul 2016, lines with the 2BS QTL had significantly lower severities than lines that lacked both resistance alleles. In the combined data across all years, lines with the 2BS and 3BS QTLs individually had significantly lower severities than lines that lacked both QTLs.

\section{DISCUSSION}

AC Taber was determined to have two adult plant genes for leaf rust resistance on chromosomes $2 \mathrm{BS}$ and $3 \mathrm{BS}$. The gene on $2 \mathrm{BS}$ was Lr13. This was supported by the Thatcher line with Lr13 RL4031 and by AC Taber sharing the same alleles for markers $K$-IWA3257, $K-I W B 26224, K-I W B 1575$, and $K$-IWA50 on 2BS. The segregating RILs also had low-intermediate seedling ITs that were highly similar to the IT of RL4031 to race BBBDB. Another gene located on chromosome 2BS is Lr23 (McIntosh et al. 1995). AC Taber and the Thatcher line with $L r 23$ were not polymorphic (M. Rouse, unpublished data) when tested with KASP markers linked to Lr23 (Chhetri et al. 2017). Genes Lr23 and Lr16 (another gene that is located at the distal region of 2BS) have lower ITs in seedlings than Lr13, which expresses optimally in adult plants. Adult plants of RL4031 have very low ITs to race BBBDB (Oelke and Kolmer 2005). The RILs were also tested with an isolate of race TBBGJ that has low ITs to both Lr23 and Lr16, and all RILs had high ITs. In seedling plants, Lr13 resistance expression is enhanced by the presence of other resistance genes (Kolmer 1992). The resistance QTL on 3BS enhanced the seedling resistance of Lrl3 in the segregating RILs. The RILs with both Lr13 and the 3BS QTL had lower ITs compared with lines that had only $L r 13$ or the 3BS QTL. The QTL mapping, segregation of seedling IT, and KASP marker data confirmed the presence of Lrl3 in AC Taber (Liu and Kolmer 1997). In a genome-wide association study of spring wheat germplasm, Turner et al. (2016) determined that adult plant leaf rust resistance attributed to $L r 13$ was associated with IWA4894 that mapped at $93.46 \mathrm{cM}$ on $2 \mathrm{BS}$ in the $90 \mathrm{~K}$ consensus map (Wang et al. 2014), the same location as IWA3257 (Supplementary Table S1). In the five field tests, RL4031 had leaf rust severities and response ratings of 50 MRMS to 70S. Many spring wheat cultivars in North America have Lrl3, which was first characterized in the Brazilian cultivar Frontana (Dyck et al. 1966). Since the release of Chris in 1966, cultivars with Lrl3 have had varying levels of resistance in North America, owing to changes in the frequency of $P$. triticina races with virulence to $\operatorname{Lr} 13$.

The second gene in AC Taber that conditioned adult plant resistance was located on chromosome 3BS. This is likely the second adult plant resistance gene in AC Taber that was previously designated as LrTb (Liu and Kolmer 1997). Other genes and QTLs for leaf rust resistance have been mapped on chromosome 3BS. Gene $L r 27$ is on 3BS and when combined with Lr31 on chromosome 4BS produces a very low IT in seedling plants to specific isolates of $P$. triticina (Singh and McIntosh 1984). The RILs were also tested as seedlings with an isolate of race SBDGG, which produces a fleck IT on Gatcher (Kolmer et al. 2018) that has Lr27+ Lr31, and all of the RILs had high ITs to SBDGG. Furthermore, a QTL on 4BS was not detected in this study, which provided further evidence that the 3BS QTL in AC Taber is not Lr27. Adult plant leaf rust resistance QTLs on 3BS were previously detected in the soft red winter wheat cultivars Caldwell (Kolmer et al. 2018) and Clark (Li et al. 2017), which mapped in the same region as the 3BS QTL in AC Taber based on the location of SNP markers in the 90K consensus map (Wang et al. 2014) and the IWGSC RefSeq version 1.0 genome assembly (www.wheatgenome.org; Supplementary Table S1). Chhetri (2015) mapped the adult plant resistance gene $L r 74$ from the cultivars BT-Schomburgk and Spark on 3BS, in the same region as the 3BS QTL in Caldwell. Since the 3BS QTLs from Clark, Caldwell, and AC Taber all map in the same region and condition an intermediate level of adult plant resistance, there is a high likelihood that the same gene is present in these cultivars. The 3BS QTL in AC Taber has not been characterized previously in North American spring wheat cultivars. This resistance is most likely derived from the CIMMYT lines Tobari 66 or Romany that are in the pedigree of HY320, which is a parent of AC Taber (Knox et al. 1992). Kolmer (1994) detected Lrl3 and an additional adult plant leaf rust resistance gene in HY320. Since RILs that had the 3BS and the 2BS QTLs had lower rust severities than RILs that had either QTL singly, the 3BS QTL should be useful in combination with other effective leaf rust resistance gene(s) in wheat improvement projects.

TABLE 5. Average infection type (IT) and leaf rust severity (percent) of combinations of two leaf rust resistance quantitative trait loci in the Thatcher $\times$ AC Taber recombinant inbred lines (RILs) in seedlings and in five field tests

\begin{tabular}{|c|c|c|c|c|c|c|c|c|c|c|}
\hline \multirow[b]{2}{*}{ Genotype } & \multicolumn{3}{|c|}{ Seedling tests } & \multicolumn{7}{|c|}{ Field tests } \\
\hline & $\begin{array}{l}\text { RILs } \\
(n)\end{array}$ & $\begin{array}{l}\text { BBBDB-1w } \\
\text { seedling IT }^{\mathrm{x}}\end{array}$ & $\begin{array}{l}\text { BBBDB- } 2^{\mathrm{y}} \\
\text { seedling IT }\end{array}$ & $\begin{array}{l}\text { RILs } \\
(n)\end{array}$ & $\begin{array}{c}\text { St. Paul } \\
2013\end{array}$ & $\begin{array}{l}\text { Crookston } \\
2013\end{array}$ & $\begin{array}{c}\text { St. Paul } \\
2014\end{array}$ & $\begin{array}{c}\text { St. Paul } \\
2015\end{array}$ & $\begin{array}{c}\text { St. Paul } \\
2016\end{array}$ & $\begin{array}{c}\text { Combined } \\
\text { years }\end{array}$ \\
\hline QLr.cdl-2BS- QLr.cdl-3BS- & 43 & $7.74 \mathrm{~A}$ & $7.81 \mathrm{~A}$ & 49 & $52.27 \mathrm{~A}^{\mathrm{z}}$ & $41.70 \mathrm{~A}$ & $57.92 \mathrm{~A}$ & $54.27 \mathrm{~A}$ & $50.61 \mathrm{~A}$ & $51.38 \mathrm{~A}$ \\
\hline QLr.cdl-2BS- QLr.cdl-3B+ & 41 & $7.13 \mathrm{~A}$ & $7.12 \mathrm{~A}$ & 40 & $38.57 \mathrm{~B}$ & $38.50 \mathrm{~A}$ & $49.00 \mathrm{~A}$ & $45.69 \mathrm{AB}$ & $44.74 \mathrm{AB}$ & $42.96 \mathrm{~B}$ \\
\hline$\widetilde{Q L r c d l}-2 B S+Q L r . c d l-3 B S-$ & 57 & $5.01 \mathrm{~B}$ & $5.04 \mathrm{~B}$ & 53 & $31.81 \mathrm{BC}$ & $36.20 \mathrm{AB}$ & $46.93 \mathrm{~A}$ & $42.69 \mathrm{BC}$ & $42.26 \mathrm{~B}$ & $40.60 \mathrm{~B}$ \\
\hline QLr.cdl-2BS+ QLr.cdl-3BS+ & 38 & $3.27 \mathrm{C}$ & $3.40 \mathrm{C}$ & 39 & $22.83 \mathrm{C}$ & $30.92 \mathrm{~B}$ & $34.23 \mathrm{~B}$ & $32.95 \mathrm{C}$ & $31.41 \mathrm{C}$ & $30.54 \mathrm{C}$ \\
\hline
\end{tabular}

w Seedling test 1 .

${ }^{x}$ Infection type (IT) scale of 1 to 9 . IT; $($ fleck) $=1$, IT4 $=9$.

y Seedling test 2 .

z Genotypes with different letters in the same column are different based on Tukey's honest significant difference in PROC GLM in SAS. 
Markers $K$-IWB23457 and $K-I W B 30730$ may be useful for selection of the 3BS QTL, and markers $K$-IWA3257, K-IWB26224, and $K$-IWB1575 will facilitate selection of Lr13. Tightly linked (Kolmer et al. 2008) and gene-specific (Lagudah et al. 2009) markers for the adult plant resistance gene $L r 34$ can be used to select breeding lines with this durable resistance gene. Breeding lines and cultivars with these three resistance genes should have high levels of long-lasting leaf rust resistance.

\section{ACKNOWLEDGMENTS}

We thank K. Xiao for excellent technical assistance, T. Lake for initial mapping of the RILs, and S. Chao for genotyping the RILs and parents. Mention of trade names or commercial products in this publication is solely for the purpose of providing specific information and does not imply recommendation or endorsement by the U.S. Department of Agriculture.

\section{LITERATURE CITED}

Akbari, M., Wenzl, P., Caig, V., Carling, J., Yang, S., Uszynski, G., Mohler, V., Lehmensiek, A., Kuchel, H., Hayden, M. J., Howes, N., Sharp, P., Vaughn, P., Rathmell, B., Huttner, E., and Kilian, A. 2006. Diversity arrays technology (DArT) for high-throughput profiling of the hexaploid wheat genome. Theor. Appl. Genet. 113:1409-1420.

Broman, K. W., Wu, H., Sen, S., and Churchill, G. A. 2003. QTL mapping in experimental crosses. Bioinformatics 19:889-890.

Chhetri, M. 2015. Molecular mapping and genetic characterization of rust resistance in wheat. Ph.D. thesis, University of Sydney, Sydney, Australia.

Chhetri, M., Bariana, H., Wong, D., Sohail, Y., Hayden, M. J., and Bansal, M. 2017. Development of robust molecular markers for marker-assisted selection of leaf rust resistance gene Lr23 in common and durum wheat breeding programs. Mol. Breed. 37:21.

Dyck, P. L., Samborski, D. J., and Anderson, R. G. 1966. Inheritance of adultplant leaf rust resistance derived from the common wheat varieties Exchange and Frontana. Can. J. Genet. Cytol. 8:665-671.

Illumina. 2011. GenomeStudio genotyping module software, release 1.0. Illumina, San Diego, CA.

Knox, R. E., De Pauw, R. M., Morrison, R. J., McCaig, T. N., Clarke, J. M., and McLeod, J. G. 1992. AC Taber red spring wheat. Can. J. Plant Sci. 72: 1241-1245.

Kolmer, J. 1994. Genetics of leaf rust resistance in three western Canada spring wheats. Plant Dis. 78:600-602.

Kolmer, J. A. 1992. Enhanced leaf rust resistance in wheat conditioned by resistance gene pairs with Lr13. Euphytica 61:123-130.

Kolmer, J. A. 2019. Virulence of Puccinia triticina, the wheat leaf rust fungus, in the United States in 2017. Plant Dis. 103:2113-2120.

Kolmer, J. A., Chao, S., Brown-Guedira, G., Bansal, U., and Bariana, H. 2018. Adult plant leaf rust resistance derived from the soft red winter wheat cultivar 'Caldwell' maps to chromosome 3BS. Crop Sci. 58:152-158.

Kolmer, J. A., and Hughes, M. E. 2015. Physiologic specialization of Puccinia triticina on wheat in the United States in 2013. Plant Dis. 99:1261-1267.

Kolmer, J. A., and Hughes, M. E. 2017. Physiologic specialization of Puccinia triticina on wheat in the United States in 2015. Plant Dis. 107: 1496-1506.

Kolmer, J. A., and Hughes, M. E. 2018. Physiologic specialization of Puccinia triticina on wheat in the United States in 2016. Plant Dis. 102:1066-1071.

Kolmer, J. A., Long, D. L., Kosman, E., and Hughes, M. E. 2003. Physiologic specialization of Puccinia triticina on wheat in the United States in 2001. Plant Dis. 87:859-866.
Kolmer, J. A., Singh, R. P., Garvin, D. F., Viccars, L., William, H. M., Huerta-Espino, J. H., Obonnaya, F. C., Raman, H., Orford, S., Bariana, H. S., and Lagudah, E. S. 2008. Analysis of the Lr34/Yrl8 rust resistance region in wheat germplasm. Crop Sci. 48:1841-1852.

Lagudah, E. S., Krattinger, S. G., Herrera-Foessel, S. A., Singh, R. P., Huerta-Espino, J., Spielmeyer, W., Brown-Guedira, G., Selter, L., and Keller, B. 2009. Gene-specific markers for the wheat gene Lr34/Yrl 18 which confers resistance to multiple fungal pathogens. Theor. Appl. Genet. 119: 889-898.

Lander, E. S., Green, P., Abrahamson, J., Barlow, A., Daly, M. J., Lincoln, S. E., and Newburg, L. 1987. MAPMAKER: An interactive computer package for constructing primary genetic linkage maps of experimental and natural populations. Genomics 1:174-181.

LGC Genomics. 2013. KASP genotyping chemistry: User guide and manual. https://biosearch-cdn.azureedge.net/assetsv6/KASP-genotyping-chemistryUser-guide.pdf

Li, C., Wang, Z., Li, C., Bowden, R., Bai, G., Li, C., Li, C., Su, Z., and Carver, B. F. 2017. Mapping of quantitative trait loci for leaf rust resistance in the wheat population Ning $7840 \times$ Clark. Plant Dis. 101:1974-1979.

Liu, J. Q., and Kolmer, J. A. 1997. Genetics of leaf rust resistance in Canadian spring wheats AC Domain and AC Taber. Plant Dis. 81:757-760.

Long, D. L., and Kolmer, J. A. 1989. A North American system of nomenclature for Puccinia recondita f. sp. tritici. Phytopathology 79:525-529.

McCallum, B., Seto-Goh, P., Foster, A., and Xue, A. 2018. Physiological specialization of Puccinia triticina, the causal agent of wheat leaf rust, in Canada in 2012. Can. J. Phytopathol. 40:434-441.

McIntosh, R. A., Wellings, C. R., and Park, R. F. 1995. Wheat rusts: An atlas of resistance genes. CSIRO, Kluwer Academic Publishers, Dordrecht, The Netherlands.

Meng, L., Li, H., Zhang, L., and Wang, J. 2015. QTL ICImapping: Integrated software for genetic linkage map construction and quantitative trait locus mapping in biparental populations. Crop J. 3:269-283.

Nelson, J. C. 1997. QGENE: Software for marker-based genomic analysis and breeding. Mol. Breed. 3:239-245.

Oelke, L. M., and Kolmer, J. A. 2004. Characterization of leaf rust resistance in hard red spring wheat cultivars. Plant Dis. 88:1127-1133.

Oelke, L. M., and Kolmer, J. A. 2005. Genetics of leaf rust resistance in spring wheat cultivars Norm and Alsen. Phytopathology 95:773-778.

Peterson, R. F., Campbell, A. B., and Hannah, A. E. 1948. A diagrammatic scale for estimating rust intensity on leaves and stems of cereals. Can. J. Res. 26:496-500.

Saari, E. E., and Prescott, J. M. 1985. World distribution in relation to economic losses. Pages 259-298 in: The cereal rusts. A. P. Roelfs and W. R. Bushnell, eds. Academic Press, Orlando, FL.

SAS. 2012. The SAS system for Windows. Release 9.4. SAS Institute, Cary, NC.

Singh, R. P., and McIntosh, R. A. 1984. Complementary genes for reaction to Puccinia recondita tritici in Triticum aestivum. I. Genetic and linkage studies. Can. J. Genet. Cytol. 26:723-735.

Turner, M. K., Kolmer, J. A., Pumphrey, M. O., Bulli, P., Chao, S., and Anderson, J. A. 2016. Association mapping of leaf rust resistance loci in a spring wheat core collection. Theor. Appl. Genet. 130:345-361.

Wang, S., Wong, D., Forrest, K., Allen, A., Chao, S., Huang, B. E., Maccaferri, M., Salvi, S., Milner, S. G., Cattivelli, L., Mastrangelo, A. M., Whan, A., Stephen, S., Barker, G., Wieseke, R., Plieske, J., Lillemo, M., Mather, D., Appels, R., Dolferus, R., Brown-Guedira, G., Korol, A., Akhunova, A. R., Feuillet, C., Salse, J., Morgante, M., Pozniak, C., Luo, M.-C., Dvorak, J., Morell, M., Dubcovsky, J., Ganal, M., Tuberosa, R., Lawley, C., Mikoulitch, I., Cavanagh, C., Edwards, K. J., Hayden, M., and Akhunov, E.; International Wheat Genome Sequencing Consortium. 2014. Characterization of polyploid wheat genomic diversity using a high-density 90000 single nucleotide polymorphism array. Plant Biotechnol. 12:787-796. 